[Radiocarbon, Vol 22, No. 3, 1980, P 684-692]

\title{
CARBON-14 IN THE SOUTHERN INDIAN OCEAN
}

\section{GEORGETTE DELIBRIAS}

Centre des Faibles Radioactivités, Laboratoire mixte CNRS-CEA, 91190 Gif sur Yvette, France

ABSTRACT. ${ }^{14} \mathrm{C}$ measurements were carried out on sea water samples collected in 1973 , in the Indian ocean. The results obtained for 9 vertical profiles between $27^{\circ} \mathrm{S}$ and $48^{\circ} \mathrm{S}$ are presented. In surface water, the bomb ${ }^{14} \mathrm{C}$ content is maximum at middle latitudes. A time lag relative to the north hemisphere bomb ${ }^{14} \mathrm{C}$ delivery is apparent. In the more southern latitudes, ${ }^{11} \mathrm{C}$ content remains very low.

\section{INTRODUCTION}

The distribution of bomb ${ }^{14} \mathrm{C}$ in the oceans has been studied by numerous authors, either to determine the residence time of carbon in the different oceanic reservoirs or to measure the velocity of displacement of water masses. Most work has been done in the Atlantic Ocean (Broecker and others, 1960; Broecker and Olson, 1961; Broecker, Peng, and Stuiver, 1978; Fairhall, Young and Bradford, 1972; Fonselius and Östlund, 1959; Östlund, Dorsey, and Rooth, 1974; Ribbat, Roether, and Munnich, 1976; Stuiver, 1976; 1978; Vogel, 1972) and in the Pacific ocean (Bien, Rakestraw, and Suess, 1963; 1965; Rafter and O'Brien, 1972; Fairhall, Young, and Bradford, 1972).

Very few data are presently available for the Indian Ocean. The only ${ }^{14} \mathrm{C}$ measurements known for that part of the ocean are given by Bien, Rakestraw, and Suess (1963; 1965). They have, very interestingly, demonstrated that when bomb ${ }^{14} \mathrm{C}$ entered the surface waters of the southern hemisphere, natural ${ }^{14} \mathrm{C}$ concentration was still preserved in the deep waters.

The present work shows the distribution of ${ }^{14} \mathrm{C}$ in the western part of the Southern Indian Ocean in 1973. Sea water samples were collected at the end of the austral summer, during the 1973 OSIRIS I hydrological expedition, on board the $R / V$ Marion Dufresne. Figure 1 shows the position of the ${ }^{14} \mathrm{C}$ stations.

\section{EXPERIMENTAL METHOD}

Water samples were collected with 30-liter Niskin bottles. Because of the limited number of bottles and of time available for the ${ }^{14} \mathrm{C}$ program, the volume of collected water was only $60 \mathrm{~L}$ down to $1000 \mathrm{~m}$ depth and $90 \mathrm{~L}$ for the deeper levels. At each depth, a reversing thermometer gave temperature measurements and some water was collected for salinity and $\Sigma \mathrm{CO}_{2}$. At each step of the sampling procedure as well as during the extraction, special attention was paid to eliminate all risk of contamination.

Inorganic carbon was extracted on board the ship in the usual manner. Immediately after sampling, the water from the bottle was transferred by pumping into a 100L metallic tank that was previously filled with nitrogen. The water was then acidified and warmed with an immersion heater to help the outgassing process. The released $\mathrm{CO}_{2}$ was then trapped in a purified $6 \mathrm{~N} \mathrm{NaOH}$ solution that was prepared previously in the laboratory under an inert atmosphere and sealed in flasks. The transfer 
of $\mathrm{CO}_{2}$ was accomplished by circulating nitrogen through the system in a closed loop using a pump.

The duration of one operation was about 4 hours for a 60L sample and 6 hours for a 90L sample. Upon return to the laboratory, the alkaline solution was placed under vacuum and quickly acidified with $\mathrm{H}_{2} \mathrm{SO}_{4}$. The $\mathrm{CO}_{2}$ removed, after drying and purification, was counted for ${ }^{14} \mathrm{C}$ activity. Although shipboard operations were carried out very carefully, extraction of $\mathrm{CO}_{2}$ was not always complete, partly because of lack of time during the stations. The volume of $\mathrm{CO}_{2}$ available for ${ }^{14} \mathrm{C}$ measurements thus varied from 2 to $3.5 \mathrm{~L}$. Two different 1.2L proportional counters, having 1.06 and $1.27 \mathrm{cpm}$, respectively, as backgrounds, were used for counting. Corrections for isotopic fractionation and calculations of the usual $\Delta^{14} \mathrm{C}$ values were effected using $\delta^{13} \mathrm{C}$ measurements made on the $\mathrm{CO}_{2}$ filling the proportional counters, after the ${ }^{14} \mathrm{C}$ measurements. The average of the measured $\delta^{13} \mathrm{C},+0.02 \%$, was adopted for correction, in some cases, when $\delta^{13} \mathrm{C}$ measurements were missing. The experimental dispersion around this average value was then included in the calculation of the errors on $\Delta^{14} \mathrm{C}$

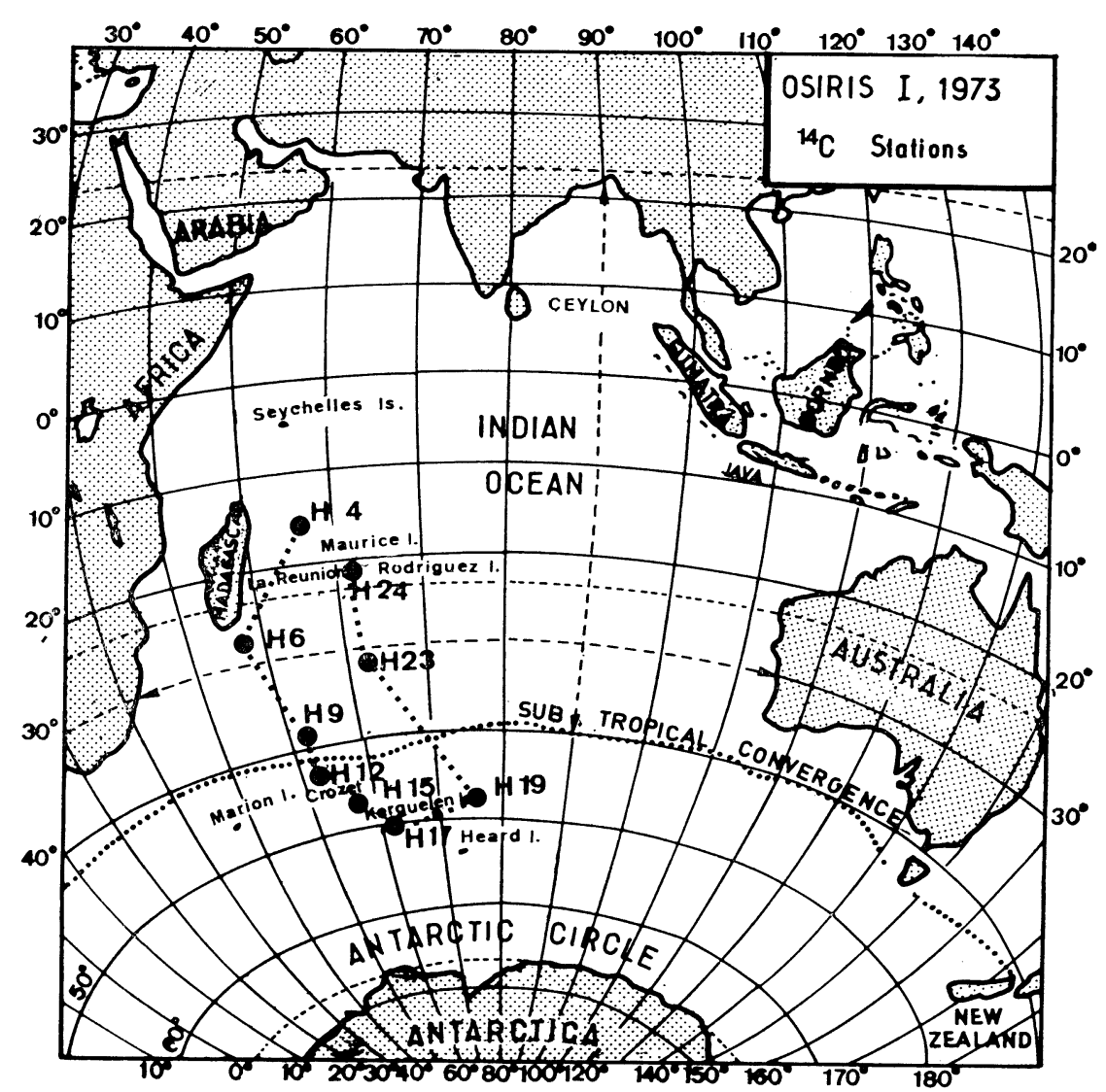

Fig. 1. Map showing the track of the ship, with the location of ${ }^{14} \mathrm{C}$ stations. 
( $\pm 4 \%$ added). Accuracy obtained for $\Delta^{14} \mathrm{C}$ measurements is $\pm 6 \%$, in most cases, but it is very variable (from $\pm 4 \%$ o to $\pm 10 \%$ ) mainly because of the varying amount of carbon available for measurement and the missing $\delta^{13} \mathrm{C}$ measurements.

The value of modern carbon used as reference was the NBS oxalic activity $\times 0.95$, corrected for decay from 1950 to 1973 , the year of the water sampling.

\section{RESULTS}

All ${ }^{14} \mathrm{C}$ data and $\delta^{13} \mathrm{C}$ measurements are shown in table 1 with the location of the stations arranged from north to south. Salinity and $\Sigma \mathrm{CO}_{2}$ data (Le Floc'h and Tanguy, 1973) given in the same table were obtained from water collected in a separate bottle at the same time as the ${ }^{14} \mathrm{C}$ samples. Variations in $\Delta^{14} \mathrm{C}$ values obtained in 1973 with depth and latitude of the sampling in the Southern Indian Ocean are of interest. Although evidence of bomb ${ }^{14} \mathrm{C}$ is present in most samples from upper levels of the water column, this is often not the case for deep levels. Consequently, it will often be necessary to refer to the available pre-atomic values.

\section{Surface waters}

\section{Pre-nuclear bomb ${ }^{14} \mathrm{C}$ levels in the Indian ocean}

The natural ${ }^{14} \mathrm{C}$ level of ocean surface water in the Indian Ocean is not well known. To obtain precise values, we measured the activity of two shells collected alive on a specific date that were carefully preserved in a collection:

- Cyprata mauritania, living in 1914, at Maurice Island $\left(13^{\circ} 25^{\prime} \mathrm{S}, 48^{\circ}\right.$ $\left.30^{\prime} \mathrm{E}\right)$. The apparent age found is $399 \pm 35$ years, corresponding to a $\Delta^{14} \mathrm{C}$ of $-47.2 \pm 4 \%$ (Gif-4064).

- C carneala, living in 1853, at Nossibe, Madagascar $\left(20^{\circ} 15^{\prime} \mathrm{S}, 57^{\circ} 30^{\prime}\right.$ $\mathrm{E})$. The apparent age is $350 \pm 35$ years, corresponding to a $\Delta^{14} \mathrm{C}$ of -41.5 $\pm 4 \%$ (Gif-4065).

These values are corrected for radioactive decay and isotopic fractionation. Some values obtained at the very beginning of the ${ }^{14} \mathrm{C}$ bomb advent for surface water, south of the Antarctic convergence, are reported: $-57^{\circ} 07^{\prime} \mathrm{S}, 07^{\circ} 05^{\prime} \mathrm{W},\left(\theta=+1^{\circ} \mathrm{C}\right)$, in 1958: $\Delta^{14} \mathrm{C}=-120 \pm 5 \%$ (Broecker and others, 1960)

$-55^{\circ} 27^{\prime} \mathrm{S}, 57^{\circ} 10^{\prime} \mathrm{W},\left(\theta=+3^{\circ} \mathrm{C}\right.$ ), in 1958: $\Delta^{14} \mathrm{C}=-111 \pm 7 \%$ (Broecker and others, 1960)

$-64^{\circ} 11^{\prime} \mathrm{S}, 168^{\circ} 58^{\prime} \mathrm{W},\left(\theta=+1.7^{\circ} \mathrm{C}\right)$, in $1961: \Delta^{14} \mathrm{C}=-120 \pm 20^{\%} \%$ (L J-410) (Bien, Rakestraw, and Suess, 1965).

Although obtained in the South Atlantic and South Pacific Oceans, these values are important for comparison with our present data, if Antarctic surface water is considered to be well mixed in the circumpolar region. We can also use the $\Delta^{14} \mathrm{C}$ value of $-149 \pm 7 \%$ (L-570) given for the flesh of a seal killed in 1959 (Broecker and others, 1960) at Mac Murdo, $\left(77^{\circ} \mathrm{S}, 164^{\circ} \mathrm{E}\right)$. These very low surface water values are due to the presence of uplifted, deep, old water, which do not remain at the surface long enough to reach equilibrium with the atmosphere. 
TABLE 1

\begin{tabular}{|c|c|c|c|c|c|c|c|c|c|c|c|c|}
\hline $\begin{array}{l}\text { Satinpling } \\
\text { date }\end{array}$ & Station & l.aticude & Longitude & $\begin{array}{l}\text { Depth } \\
\text { (m) }\end{array}$ & Salinity & $\begin{array}{l}\text { Temperature } \\
\left({ }^{\circ} \mathrm{C}\right)\end{array}$ & $\stackrel{\mathrm{CO}_{2}}{\mathrm{~m}} \mathrm{~mole} / \mathrm{1}$ & $\begin{array}{r}\delta^{14} \mathrm{C} \\
\%\end{array}$ & $\begin{array}{c}\delta^{13} c^{*} \\
\%\end{array}$ & $\begin{array}{l}\therefore 140 \\
\%\end{array}$ & & $\begin{array}{l}\text { Sanuple } \\
\text { no. }\end{array}$ \\
\hline $5 / 6 / 73$ & $\begin{array}{c}\mathrm{H4} \\
\text { Betcom: } \\
4370 \mathrm{~m}\end{array}$ & $15^{\circ} 05^{\prime} \mathrm{s}$ & $55^{\circ} 31^{\prime} \mathrm{E}$ & $\begin{array}{r}0 \\
50 \\
100 \\
1000 \\
1500\end{array}$ & $\begin{array}{l}34.80 \\
34.85 \\
35.10 \\
34.70 \\
34.68\end{array}$ & $\begin{array}{l}28 \\
27.5 \\
21.55 \\
5.54 \\
3.65\end{array}$ & $\begin{array}{l}2.084 \\
2.042 \\
2.147 \\
2.325 \\
2.384\end{array}$ & $\begin{array}{l}+158 \\
+152 \\
+166 \\
-\quad 69 \\
-114\end{array}$ & $\begin{array}{c}+1.27 \\
(+0.02) \\
-1.35 \\
-1.05 \\
+0.41\end{array}$ & $\begin{array}{r}+97 \\
+94 \\
+111 \\
-113 \\
-164\end{array}$ & $\begin{array}{l} \pm 7 \\
\pm 11) \\
\pm 7 \\
\pm 7 \\
\pm 6\end{array}$ & $\begin{array}{l}\text { Gif-3113 } \\
\text { Gif-3160 } \\
\text { Gif-3163 } \\
\text { Gif-3125 } \\
\text { Gif-3126 }\end{array}$ \\
\hline $6 / 2 / 7.3$ & $\begin{array}{l}\text { H24 } \\
\text { Bottom: } \\
3475 \mathrm{~m}\end{array}$ & $20^{\circ} 30^{\prime} \mathrm{S}$ & $61^{\circ} 58^{\prime} \mathrm{E}$ & $\begin{array}{r}0 \\
50 \\
100 \\
200 \\
300 \\
700 \\
1000 \\
1500 \\
2000\end{array}$ & $\begin{array}{l}34.88 \\
35.15 \\
35.36 \\
35.56 \\
35.42 \\
34.68 \\
34.79 \\
34.72\end{array}$ & $\begin{array}{l}25.9 \\
25.5 \\
21.6 \\
18.7 \\
14.7 \\
\\
6.18 \\
3.29 \\
3.86\end{array}$ & $\begin{array}{l}2.090 \\
2.072 \\
2.146 \\
2.220 \\
2.239 \\
2.251 \\
2.291 \\
2.365 \\
2.347\end{array}$ & $\begin{array}{l}+138 \\
+183 \\
+172 \\
+152 \\
+141 \\
+36 \\
-92 \\
-83 \\
-93\end{array}$ & $\begin{array}{c}+0.43 \\
-2.81 \\
+1.13 \\
+1.49 \\
(+0.02) \\
+0.13 \\
+0.91 \\
(+0.02) \\
-4.3\end{array}$ & $\begin{array}{l}+80 \\
+130 \\
+111 \\
+91 \\
++84 \\
-16 \\
-139.5 \\
(-129 \\
-130.5\end{array}$ & $\begin{array}{l} \pm 6 \\
\pm 9 \\
\pm 5 \\
\pm 5 \\
\pm 6 \\
\pm 10) \\
\pm 6 \\
\pm \pm 5 \\
\pm(2) \\
5 \pm 6\end{array}$ & $\begin{array}{l}\text { Gif-3106 } \\
\text { Gif-3158 } \\
\text { Gif-3157 } \\
\text { Gif-3156 } \\
\text { Gif-3155 } \\
\text { Gif-3153 } \\
\text { Gif-3144 } \\
\text { Gif-3143 } \\
\text { Gif-3142 }\end{array}$ \\
\hline $5 / 9 / 73$ & H6 & $26^{\circ} 48^{\prime} \mathrm{s}$ & $48^{\circ} 39^{\prime} \mathrm{E}$ & $\begin{array}{r}0 \\
100 \\
500 \\
700 \\
1500 \\
2000 \\
3000\end{array}$ & $\begin{array}{l}35.01 \\
35.43 \\
35.12 \\
34.78 \\
34.57 \\
34.72 \\
34.74\end{array}$ & $\begin{array}{l}24.1 \\
19.14 \\
11.99 \\
9.41 \\
3.22 \\
2.44 \\
1.84\end{array}$ & $\begin{array}{l}2.09 \\
2.146 \\
2.216 \\
2.251 \\
2.365 \\
2.347 \\
2.347\end{array}$ & $\begin{array}{l}+175 \\
+217 \\
+\quad 82 \\
+\quad 26 \\
-81 \\
-99 \\
-134\end{array}$ & $\begin{array}{l}+0.76 \\
+1.27 \\
+1.27 \\
+2.16 \\
-0.80 \\
+1.27 \\
-0.11\end{array}$ & $\begin{array}{l}+114 \\
+153 \\
+47 \\
-30 \\
-128 \\
-128 \\
-177\end{array}$ & $\begin{array}{l} \pm 5 \\
\pm 10 \\
\pm 10 \\
\pm 6 \\
\pm 6 \\
\pm 6 \\
\pm 5\end{array}$ & $\begin{array}{l}\text { Gif-3100 } \\
\text { Gif-3107 } \\
\text { Gif-3108 } \\
\text { Gif-3109 } \\
\text { Gif-3110 } \\
\text { Gif-3111 } \\
\text { Gif-3112 }\end{array}$ \\
\hline $5 / 28 / 73$ & $\begin{array}{l}\text { Bot tom: } \\
4160 \mathrm{~m}\end{array}$ & $31^{\circ} 00^{\prime} \mathrm{s}$ & $61^{\circ} 51^{\prime} \mathrm{E}$ & $\begin{array}{r}0 \\
50 \\
100 \\
200 \\
300 \\
500 \\
700 \\
1000 \\
1500 \\
2000 \\
3000\end{array}$ & $\begin{array}{l}35.52 \\
35.51 \\
35.49 \\
35.37 \\
35.29 \\
35.14 \\
35.04 \\
34.52 \\
34.52 \\
34.68 \\
34.75\end{array}$ & $\begin{array}{r}19.31 \\
19.15 \\
17.17 \\
14.41 \\
13.40 \\
12.16 \\
11.32 \\
6.95 \\
3.19 \\
2.48 \\
1.79\end{array}$ & $\begin{array}{l}2.090 \\
2.072 \\
2.146 \\
2.220 \\
2.239 \\
2.216 \\
2.251 \\
2.291 \\
2.365 \\
2.347 \\
2.347\end{array}$ & $\begin{array}{l}+179.5 \\
+205 \\
+186 \\
+123 \\
+134 \\
+87 \\
+70 \\
-39 \\
-52 \\
-97 \\
-89\end{array}$ & $\begin{array}{l}+1.27 \\
+0.71 \\
+0.94 \\
+1.17 \\
+1.17 \\
+1.27 \\
+1.01 \\
-1.09 \\
+1.27 \\
+0.86 \\
+1.27\end{array}$ & $\begin{array}{l}+115.5 \\
+143 \\
+124 \\
+64 \\
+75 \\
+29 \\
+14 \\
-85 \\
-102 \\
-143 \\
-146\end{array}$ & $\begin{array}{l}5 \pm 6 \\
\pm 6 \\
\pm 6 \\
\pm 6 \\
\pm 6 \\
\pm 10 \\
\pm 5 \\
\pm 10 \\
\pm 10 \\
\pm 6 \\
\pm 5\end{array}$ & $\begin{array}{l}\text { Gif-3105 } \\
\text { Gif-3115 } \\
\text { Gif-3116 } \\
\text { Gif-3117 } \\
\text { Gif-3118 } \\
\text { Gif-3119 } \\
\text { Gif-3120 } \\
\text { Gif-3121 } \\
\text { Gif-3122 } \\
\text { Gif-3123 } \\
\text { Gif-3124 }\end{array}$ \\
\hline $5 / 14 / 73$ & $\begin{array}{l}\text { Bottuin: } \\
\text { 3680m }\end{array}$ & $38^{\circ} 42^{\prime} \mathrm{s}$ & $50^{\circ} 37^{\prime} \mathrm{E}$ & $\begin{array}{r}0 \\
100 \\
600 \\
1000 \\
1500 \\
2000 \\
3000\end{array}$ & $\begin{array}{l}35.50 \\
35.55 \\
35.21 \\
34.81 \\
34.46 \\
34.65 \\
34.76\end{array}$ & $\begin{array}{r}16.97 \\
16.99 \\
12.96 \\
8.15 \\
3.58 \\
2.79 \\
\therefore .8 !\end{array}$ & $\begin{array}{l}2.146 \\
2.145 \\
2.193 \\
2.258 \\
2.348 \\
2.321 \\
2.300\end{array}$ & $\begin{array}{l}+150 \\
+178.5 \\
+\quad 64 \\
+13 \\
-45 \\
-103 \\
-79\end{array}$ & $\begin{array}{c}+1.02 \\
-0.08 \\
-1.93 \\
+1.53 \\
(+0.02) \\
-0.63 \\
(+0.02)\end{array}$ & $\begin{array}{l}+90 \\
+120 \\
+15 \\
-48 \\
(-93 \\
-146 \\
(-125\end{array}$ & $\begin{array}{l} \pm 6 \\
\pm 8 \\
\pm 10 \\
\pm 6 \\
\pm 15) \\
\pm 6 \\
\pm 10 ;\end{array}$ & $\begin{array}{l}\text { Gif-3101 } \\
\text { Gif-3136 } \\
\text { Gif-3137 } \\
\text { Gif-3138 } \\
\text { Gif-3139 } \\
\text { Gif-3140 } \\
\text { Gif 3i4i }\end{array}$ \\
\hline $5 / 16 / 73$ & $\begin{array}{l}\text { H12 } \\
\text { Bottom: } \\
3300 \mathrm{~m}\end{array}$ & $43^{\circ} 48^{\prime} \mathrm{s}$ & $51^{\circ} 17^{\prime} \mathrm{E}$ & $\begin{array}{r}50 \\
100 \\
200 \\
300 \\
500 \\
700 \\
1000 \\
1500\end{array}$ & $\begin{array}{l}33.79 \\
33.86 \\
33.96 \\
34.13 \\
34.30 \\
34.51 \\
34.61 \\
34.73\end{array}$ & $\begin{array}{l}7.42 \\
4.87 \\
3.07 \\
3.08 \\
2.33 \\
2.31 \\
2.36 \\
2.24\end{array}$ & $\begin{array}{l}2.200 \\
2.200 \\
2.260 \\
2.287 \\
2.319 \\
2.342 \\
2.361\end{array}$ & $\begin{array}{l}+95 \\
-11 \\
=\quad 5.5 \\
=7 \\
=\quad 8.5 \\
=37 \\
=75 \\
-71\end{array}$ & $\begin{array}{l}-1.64 \\
+0.85 \\
-2.41 \\
-1.39 \\
-2.56 \\
-2.18 \\
-1.44 \\
-0.76\end{array}$ & $\begin{array}{l}+44 \\
-62 \\
-50 \\
-54 \\
-52 \\
-90 \\
-102 \\
-118\end{array}$ & $\begin{array}{l} \pm 8 \\
\pm 6 \\
\pm 9 \\
\pm 5 \\
\pm 4 \\
\pm 6 \\
\pm 8 \\
\pm 5\end{array}$ & $\begin{array}{l}\text { Gif-3161 } \\
\text { Gif-3165 } \\
\text { Gif-3166 } \\
\text { Gif-3167 } \\
\text { Gif-3168 } \\
\text { Gif-3169 } \\
\text { Gif-3170 } \\
\text { Gif-3128 }\end{array}$ \\
\hline $5 / 18 / 73$ & $\begin{array}{l}\text { HIS } \\
\text { Bottom: } \\
4560 \mathrm{~m}\end{array}$ & $46^{\circ} 54^{\prime} \mathrm{S}$ & $58^{\circ} 11^{\prime} \mathrm{E}$ & $\begin{array}{r}0 \\
1000 \\
1500 \\
3000\end{array}$ & $\begin{array}{l}34.02 \\
34.51 \\
34.71\end{array}$ & $\begin{array}{l}8.50 \\
2.44 \\
2.28\end{array}$ & $\begin{array}{l}2.190 \\
2.353 \\
2.330\end{array}$ & $\begin{array}{l}+111 \\
-77 \\
-75 \\
-68\end{array}$ & $\begin{array}{l}+1.13 \\
-1.59 \\
+2.76 \\
-2.37\end{array}$ & $\begin{array}{l}+41 \\
-120 \\
-126 \\
-111\end{array}$ & $\begin{array}{l} \pm 7 \\
\pm 6 \\
\pm 6 \\
\pm 6\end{array}$ & $\begin{array}{l}\text { Gif }-3102 \\
\text { Gif }-3171 \\
\text { Gif }-3130 \\
\text { Gif }-3132\end{array}$ \\
\hline $5 / 23 / 73$ & $\begin{array}{l}\text { Bot ton: } \\
3360 \mathrm{mn}\end{array}$ & $47^{\circ} 05^{\prime} \mathrm{s}$ & $75^{\circ} 47^{\prime} \mathrm{E}$ & $\begin{array}{r}0 \\
50 \\
100 \\
200 \\
300 \\
500 \\
700 \\
1000 \\
1500 \\
2000\end{array}$ & $\begin{array}{l}33.74 \\
33.70 \\
33.70 \\
34.25 \\
34.25 \\
34.30 \\
34.52 \\
34.71 \\
34.71\end{array}$ & $\begin{array}{l}7.82 \\
6.49 \\
6.81 \\
6.18 \\
4.58 \\
3.51 \\
2.41 \\
2.37 \\
2.08\end{array}$ & $\begin{array}{l}2.188 \\
2.174 \\
2.171 \\
2.185 \\
2.234 \\
2.271 \\
2.327 \\
2.329 \\
2.353 \\
2.376\end{array}$ & $\begin{array}{l}+105 \\
+80 \\
+98 \\
+57 \\
+57 \\
-\quad 6 \\
+22 \\
-85 \\
-76 \\
-74\end{array}$ & $\begin{array}{l}+2.76 \\
+1.68 \\
-0.45 \\
-0.07 \\
-2.22 \\
-0.80 \\
-0.84 \\
(+0.02) \\
(+0.02) \\
(+0.02)\end{array}$ & $\begin{array}{l}+44 \\
+22 \\
+44 \\
+42 \\
+4 \\
-53 \\
-27 \\
(-130 \\
(-122 \\
(-120\end{array}$ & $\begin{array}{l} \pm 6 \\
\pm 8 \\
\pm 5 \\
\pm 5 \\
\pm 5 \\
\pm 5 \\
\pm 5 \\
\pm 9 \text { ) } \\
\pm 9) \\
\pm 10)\end{array}$ & $\begin{array}{l}\text { Gif-3104 } \\
\text { Gif-3162 } \\
\text { Gif-3172 } \\
\text { Gif-3173 } \\
\text { Gif-3174 } \\
\text { Gif-3175 } \\
\text { Gif-3176 } \\
\text { Gif-3133 } \\
\text { Gif-3134 } \\
\text { Gif-3135 }\end{array}$ \\
\hline $5 / 19 / 73$ & $\begin{array}{l}\text { Bottem: } \\
4400 m\end{array}$ & $48^{\circ} 60^{\prime} \mathrm{s}$ & $60^{\circ}: 3 . \mathrm{E}$ & $\begin{array}{r}0 \\
100 \\
300 \\
700 \\
1000 \\
1500 \\
2000\end{array}$ & $\begin{array}{l}33.77 \\
33.78 \\
34.18 \\
34.50 \\
34.69 \\
34.77 \\
34.76\end{array}$ & $\begin{array}{l}4.97 \\
4.68 \\
2.39 \\
2.26 \\
2.34 \\
1.98 \\
1.95\end{array}$ & $\begin{array}{l}2.227 \\
2.228 \\
2.342 \\
2.346 \\
2.369 \\
2.371 \\
2.330\end{array}$ & $\begin{array}{l}+41 \\
+89 \\
-\quad 17 \\
-66 \\
-93 \\
-80 \\
-66\end{array}$ & $\begin{array}{c}+2.81 \\
+1.04 \\
+0.85 \\
+0.22 \\
+2.46 \\
(+0.02) \\
+2.31\end{array}$ & $\begin{array}{l}-17 \\
+34 \\
-65 \\
-113 \\
-114 \\
(-126 \\
-117\end{array}$ & $\begin{array}{l} \pm 5 \\
\pm 6 \\
\pm 6 \\
\pm 5 \\
\pm 5 \\
\pm 10) \\
\pm 6\end{array}$ & $\begin{array}{l}\text { Gif-3103 } \\
\text { Gif-3151 } \\
\text { Gif-3150 } \\
\text { Gif-3148 } \\
\text { Gif-3147 } \\
\text { Gif-3146 } \\
\text { Gif-3145 }\end{array}$ \\
\hline $12 / 12 / 74$ & & $55^{\circ} 41^{\prime} \mathrm{s}$ & $143^{\circ} 56^{\prime} \mathrm{E}$ & 0 & & 3.3 & & +17 & +1.0 & -36 & \pm 6 & Gif-3177 \\
\hline $2 / 16 / 75$ & & $66^{\circ} 40^{\prime} \mathrm{s}$ & $140^{\circ} 00^{\prime} \mathrm{E}$ & 0 & & -1 & & -90.2 & -1.83 & -132 & \pm 6 & Gif -3178 \\
\hline
\end{tabular}

${ }^{*} \delta^{13} \mathrm{C}$ values betwcen brackets does not correspond to individual measures but to an average value of the $\phi^{13} \mathrm{C}$ given in the table. The $\Delta^{14} \mathrm{C}$ values between brackets are calculated from this mean value $(+0.02)$. 
$\Delta^{14} \mathrm{C}$ in surface waters collected at $0 \mathrm{~m}$ depth in 1973

$\Delta^{14} \mathrm{C}$ values obtained for surface water, in the western part of the southern Indian Ocean in 1973 are plotted versus latitude in figure 2. The most striking feature of the observed variation is a monotonous decrease from north to south, down to some very low $\Delta^{14} \mathrm{C}$ values for the most southern latitudes. It may be observed that,

- from $15^{\circ}$ to $40^{\circ} \mathrm{S}$, in the subtropical zone, $\Delta^{14} \mathrm{C}$ values are fairly high, from $+80 \%$ to $+120 \%$. An activity maximum is situated around $30^{\circ} \mathrm{S}$ where $\Delta^{14} \mathrm{C}$ reaches values of $+114 \pm 5 \%$ at $\mathrm{H} 6$ station $\left(26^{\circ} 48^{\prime} \mathrm{S}\right)$ and $+117 \pm 6 \%$ at $\mathrm{H} 23$ station $\left(31^{\circ} \mathrm{S}\right)$;

- south of $40^{\circ} \mathrm{S}, \Delta^{14} \mathrm{C}$ decreases rapidly as do water surface temperatures; when the Antarctic Convergence is reached at station $\mathrm{Hl} 17\left(48^{\circ} 59^{\prime}\right.$ S), $\Delta^{14} \mathrm{C}$ becomes negative: $-17 \%$, the temperature being $4^{\circ} 97 \mathrm{C}$.

Compared to the 1962 values (Bien, Rakestraw, and Suess, 1965) $-56 \pm 9 \%$ at $51^{\circ} 07^{\prime} \mathrm{S}, 65^{\circ} 51^{\prime} \mathrm{E}$, and $-45 \pm 10 \%$ at $49^{\circ} 29^{\prime} \mathrm{S}, 132^{\circ} 17^{\prime}$ $\mathrm{E}$, the 1973 value, nevertheless, shows appreciably increased activity due to bomb ${ }^{14} \mathrm{C}$.

Further south, but to the east, we obtained two water surface samples in 1975, one taken from the $R V$ Thaladan $\left(55^{\circ} 41^{\prime} \mathrm{S}\right)$ and another at the foot of the Astrolabe glacier in Terre Adélie, Antarctica. For these two samples, $\mathrm{CO}_{2}$ extraction was performed in the laboratory. Results obtained are included in figure $2 . \Delta^{14} \mathrm{C}$ shows a very negative value, $-132 \%$ at $66^{\circ} 40^{\prime} \mathrm{S}, 140^{\circ} \mathrm{E}\left(\theta=-1^{\circ} \mathrm{C}\right)$, which may be due partly to the melting of old glacier water. However, it is close to the $-128 \%$ value found in 1958, at $66^{\circ} 29^{\prime} \mathrm{S}, 170^{\circ} 55^{\prime} \mathrm{E}$ (Rafter and O'Brien, 1972).

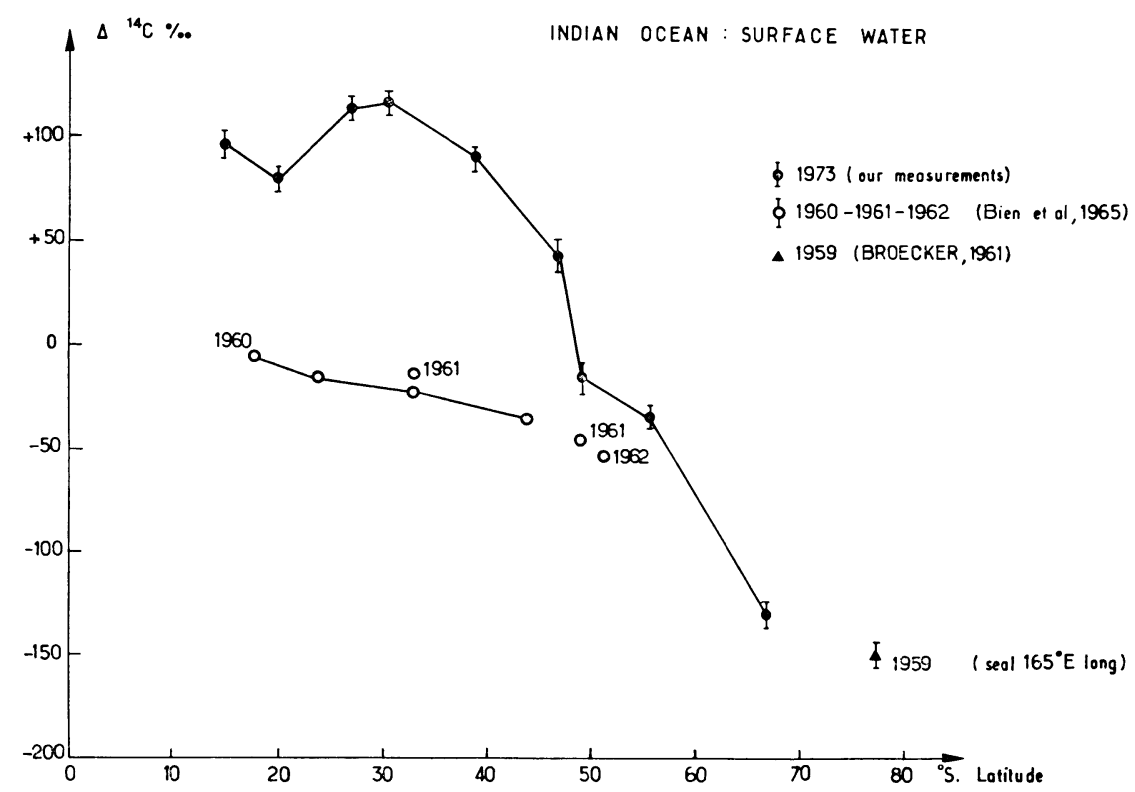




\section{Vertical distribution}

The vertical distribution of $\Delta^{14} \mathrm{C}$ for the 9 stations studied is given in figure 3. A similar trend is apparent for all the profiles. The influence of bomb ${ }^{14} \mathrm{C}$ appears clearly in the upper few hundred meters, in which $\Delta^{14} \mathrm{C}$ shows great variability. Below $1000 \mathrm{~m}$ depth, $\Delta^{14} \mathrm{C}$ decreases rapidly, becoming very negative and almost constant for all the deepest levels. There are some noticeable differences between the profiles, however, depending on their latitudes.

Most of the profiles are of the subtropical region, where $\Delta^{14} \mathrm{C}$ values are particularly high, often greater than $+100 \%$ for the first 200 to $300 \mathrm{~m}$. Penetration of bomb ${ }^{14} \mathrm{C}$ from the surface is evident and is maximum at stations $\mathrm{H} 23$ and $\mathrm{H} 9\left(31^{\circ} \mathrm{S}\right.$ and $38^{\circ} 42^{\prime} \mathrm{S}$, respectively) where $1000 \mathrm{~m}$ depth is reached.

In order to estimate the inventory of uptake of bomb ${ }^{14} \mathrm{C}$ during the $\mathrm{CO}_{2}$ exchange in the upper $1000 \mathrm{~m}$, the difference between the 1973 and the $1960 \Delta^{14} \mathrm{C}$ values is integrated with depth (Broecker, 1978). It is done for the stations close to well-documented stations where profiles were made in 1960 for natural concentrations.

The water column inventories of bomb ${ }^{14} \mathrm{C}$, for a latitude band from $24^{\circ}$ to $39^{\circ} \mathrm{S}$, lead to a mean value of $2.4 \cdot 10^{-8} \mu$ mole of ${ }^{14} \mathrm{C} / \mathrm{cm}^{2}$, with a range of 1.96 to $2.72 \cdot 10^{-8} \mu \mathrm{mole} / \mathrm{cm}^{2}$. This yields to an overall estimate of 26 moles $/ \mathrm{m}^{2} / \mathrm{yr}$ for the $\mathrm{CO}_{2}$ exchange rate.

This is a little too high, but not significant, if compared to the rate of $22 \mathrm{moles} / \mathrm{m}^{2} / \mathrm{yr}$ (corresponding to $2.0 \cdot 10^{-8} \mu \mathrm{M} / \mathrm{cm}^{2}$ of ${ }^{14} \mathrm{C}$ ), calculated for the temperate and equatorial latitudes in the Atlantic Ocean (Broecker, 1978); but it is higher than the average of $1.7 \cdot 10^{-8} \mu \mathrm{M} / \mathrm{cm}^{2}$ of ${ }^{14} \mathrm{C}$ obtained on the GEOSECS samples for the South Pacific Ocean (Broecker, 1978).

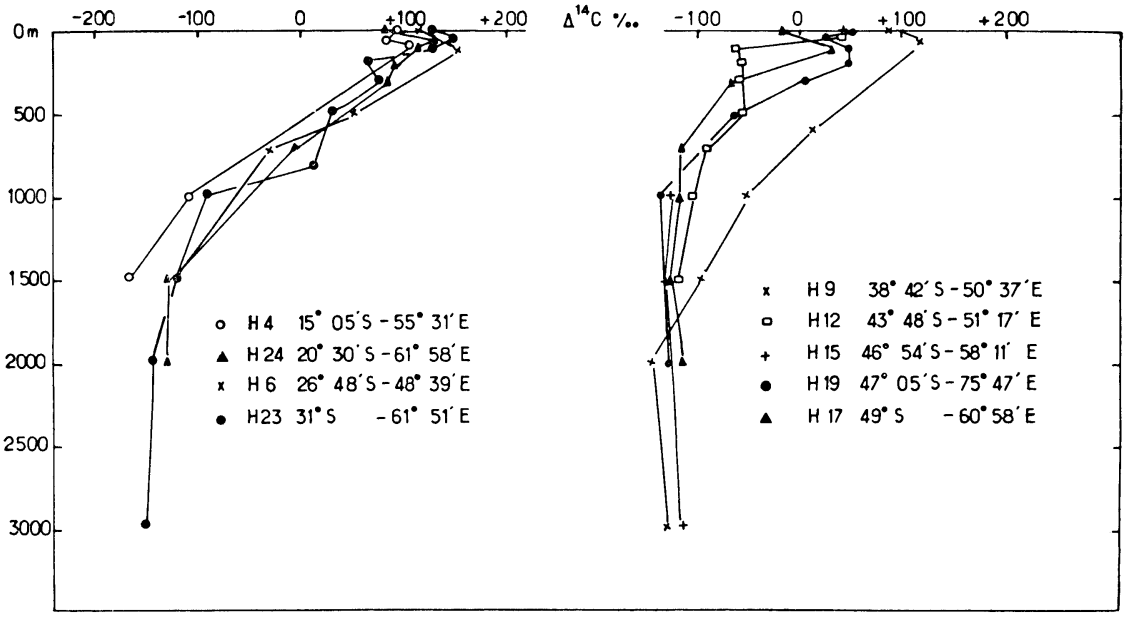

Fig 3. Vertical profiles giving the variation of ${ }^{14} \mathrm{C}$ concentration versus latitude, in the Indian Ocean, in 1973. 
The transfer to the deeper water of the bomb ${ }^{14} \mathrm{C}$ introduced at the sea-air interface, and the resemblance of the profiles can be explained by the high rate of mixing prevailing in the first $1000 \mathrm{~m}$ of water at these latitudes rather than by an appreciable difference in the $\mathrm{CO}_{2}$ exchange rate.

The three southernmost profiles, $\mathrm{H} 12, \mathrm{H} 15$, and $\mathrm{H} 19$, are in the subantarctic area. The influence of bomb ${ }^{14} \mathrm{C}$ is weaker and is only evident in the first 300 to $500 \mathrm{~m}$. The low $\Delta^{14} \mathrm{C}$ value of $-53 \pm 5 \%$, at $500 \mathrm{~m}$ depth at stations $\mathrm{H} 19$ and $\mathrm{H} 12$, does not allow for definitive data on the presence of bomb ${ }^{14} \mathrm{C}$ at this depth.

At station $\mathrm{H} 17\left(48^{\circ} 59^{\prime} \mathrm{S}\right)$ a sharp drop of surface temperature $(\theta=$ $4^{\circ} 97 \mathrm{C}$ ) indicates the proximity of the Antartic Convergence. The vertical temperature gradient, already less important in the sub-antarctic region, becomes very weak in this profile. The same thing is found for the $\Delta^{14} \mathrm{C}$ gradient. Bomb ${ }^{14} \mathrm{C}$ is evident only above 100 to $200 \mathrm{~m}$ while at $700 \mathrm{~m}$ depth $\Delta^{14} \mathrm{C}$, it is very low, $-113 \pm 5 \%$, and so it becomes difficult to decide if these values are, or are not, natural concentrations.

\section{DISCUSSION}

Two different phenomena combine to make of the middle latitudes in the South Indian Ocean (around $30^{\circ} \mathrm{S}$ ) a favored zone for the introduction of the atmospheric bomb ${ }^{14} \mathrm{C}$ into the upper part of the ocean,

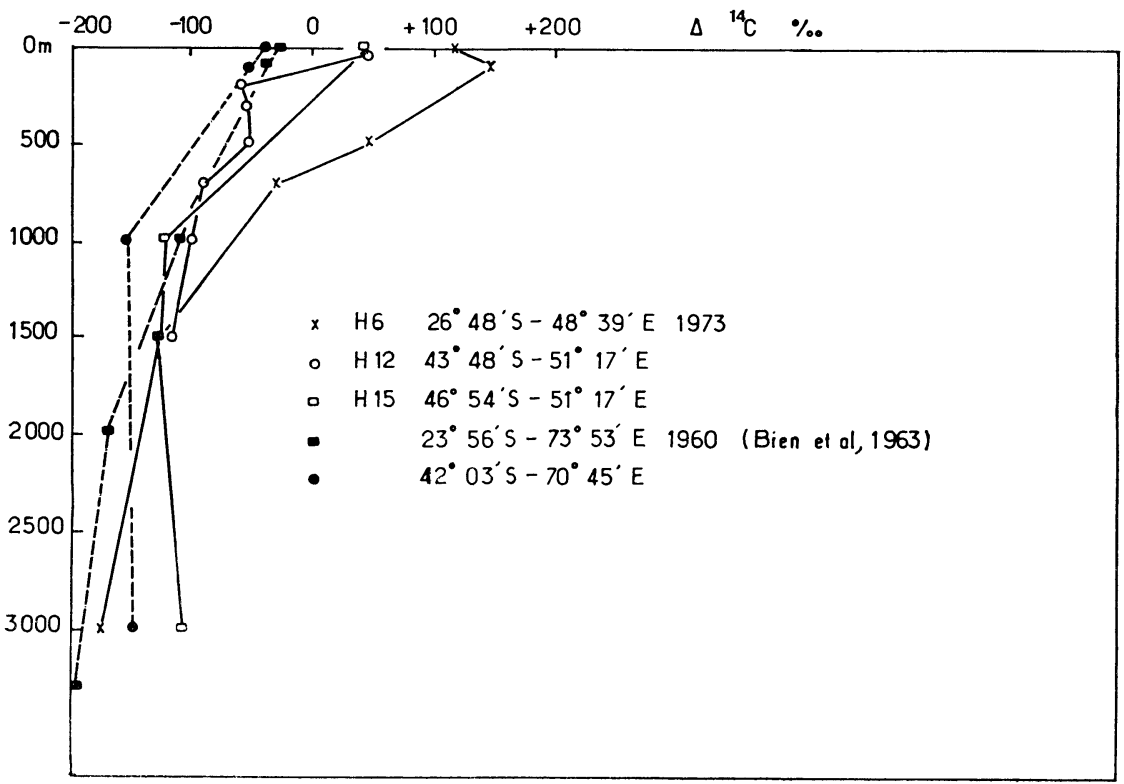

Fig 4. Comparison of $\Delta^{s:} \mathrm{C}$ vertical profiles obtained in 1973 (this study) and in 1960 (Bien, Rakestraw, and Suess, 1963). 
- intensity of the exchange of $\mathrm{CO}_{2}$ with the atmosphere, due to agitation of the sea surface,

- high mixing rate which affects the first $1000 \mathrm{~m}$ and carries down atmospheric $\mathrm{CO}_{2}$ dissolved at the surface.

The important feature of the penetration of bomb ${ }^{14} \mathrm{C}$ into surface waters at these latitudes is evidenced by comparison with the earlier data of Bien, Rakestraw, and Suess (1965), plotted in figure 2. Two profiles studied in 1960 (fig 4) show some significant differences in the very nearly vertical profiles obtained in 1973 in the upper levels of the Indian Ocean. However, the highest $\Delta^{14} \mathrm{C}$ value recorded at the surface in this study is $+117 \pm 6 \%$ when the average value, between $45^{\circ} \mathrm{N}$ and $35^{\circ} \mathrm{S}$, in 1972 in surface water of the Atlantic Ocean was $+127 \%$ (Stuiver, 1978). Thus, it seems that ${ }^{14} \mathrm{C}$ delivery to surface water, even in this particular part of the South Indian Ocean, still displayed some time lag in 1973. This was due to the fact that nuclear explosions essentially took place in the northern hemisphere and that bomb ${ }^{14} \mathrm{C}$ gradually penetrated into the southern hemisphere by exchange across the equator. Indeed, it is only since 1968-1969 that the troposphere has been completely mixed; in $1973, \Delta^{14} \mathrm{C}$ in both hemispheres was around +50 percent (our measurements).

Despite rather high $\Delta^{14} \mathrm{C}$ values found down to $1000 \mathrm{~m}$ at station $\mathrm{H} 9$ $\left(-48 \%\right.$ ), the presence of bomb ${ }^{14} \mathrm{C}$ around 1000 to $1500 \mathrm{~m}$ depth is questionable. The average $\Delta^{14} \mathrm{C}$ values for all the stations studied in 1973 , is $-121 \%$ with an important variability, from $-139 \%$ to $-85 \%$. For the same depths and similar latitude, the value was around $-110 \%$ in 1960 , also with an important dispersion, from $-120 \%$ to $-90 \%$. Consequently, it can be said that,

- these levels, on the whole, were not yet reached by bomb ${ }^{14} \mathrm{C}$ in 1973 , the two average values being similar.

- the great variability in the $\Delta^{14} \mathrm{C}$ values already existed in 1960 when the presence of bomb ${ }^{14} \mathrm{C}$ was strictly impossible at these depths.

The hydrologic study of salinity and temperature (Le Floc'h and Tanguy, 1973) allowed us to identify Antarctic Intermediate Water at these depths. This water mass derives from Surface Antarctic Water, near the Convergence. It is cold heavy water (salinity $\cong 34 \%, \theta \cong 3^{\circ} \mathrm{C}$ ) which sinks and attains density equilibrium at depth, then moves northwards, slowly mixing with waters above and below. It can be identified by a minimum in vertical salinity profiles at $34-34.5 \%$.

\section{ACKNOWLEDGMENTS}

We are very grateful to Les Terres Australes et Antarctiques Françaises, for providing the Marion Dufresne and Taladan $R V$, J C Duplessy, chief scientist of OSIRIS I hydrological expedition, and M Lesty who performed $\mathrm{CO}_{2}$ extractions on board the ship. We also thank all the members of the ${ }^{14} \mathrm{C}$ laboratory, especially $\mathrm{M} \mathrm{T}$ Guillier, and R Chesselet and L Labeyrie for their comments and discussions. 


\section{REFERENCES}

Bien, G S, Rakestraw, N W, and Suess, H E, 1963, Radiocarbon dating of deep water of Pacific and Indian Ocean: Inst Oceanog Monaco Bull, v 61, no. 1278, p 1-16.

1965. Radiocarbon in the Pacific and Indian Oceans and its relation to deep water movements: Limnology and Oceanography, v 10, supp no. 5, p R-25 R-37.

Broecker, W S, Gerard, R, Ewing, M, and Heezen, B C, 1960, Natural radiocarbon in the Atlantic Ocean: Jour Geophys Research, v 65, no. 9, p 2903-2931.

Broecker, W S and Olson, E A, 1961, Lamont radiocarbon measurements VIII: Radiocarbon, v 3, p 176-204.

Broecker, W S, Peng, T H, and Stuiver, Minze, 1978, An estimate of the upwelling rate in the Equatorial Atlantic based on the distribution of bomb radiocarbon: Jour Geophys Research, v 83, no. 12, p 6179-6186.

Delibrias, G, Guillier, M T, and Labeyrie, J, 1971, Gif natural radiocarbon measurements VI: Radiocarbon, v 13, p 213-254.

Fairhall, A W, Young, A W, and Bradford, P A, 1972, Radiocarbon in the sea, in Rafter, $T A$ and Grant-Taylor, $T$, eds, International radiocarbon dating conf, 8th, Proc: Wellington, New Zealand, Royal Soc New Zealand, C2-C16.

Fonselius, S and östlund, H G, 1959, Natural radiocarbon measurements in surface water from the North Atlantic and the Arctic Sea: Tellus, v 11, p 77-82.

Le Floc'h and Tanguy, 1973, L'hydrologie de la campagne OSIRIS I: Brest, Univ Bretagne Occidentale, Rapport interne, p 1-18.

Östlund, H G, Dorsey, H G, and Rooth, C G, 1974, Geosecs North Atlantic radiocarbon and tritium results: Earth and Planetary Sci Letters, v 23, p 69-86.

Rafter, T A and O'Brien, B J, 1972, ${ }^{14} \mathrm{C}$ measurements in the atmosphere in the South Pacific Ocean: A recalculation of the exchanges rates between the atmosphere and the ocean, in Rafter, $\mathbf{T} A$ and Grant-Taylor, $T$, eds, Internatl radiocarbon dating conf, 8th, Proc: Wellington, New Zealand, Royal Soc New Zealand, Ci17-C42.

Ribbat, B, Roether, W, and Münnich, K O, 1976, Turnover of eastern Caribbean deep water from ${ }^{14} \mathrm{C}$ measurements: Earth and Planetary Sci Letters, v 32, p 331-341.

Stuiver, Minze, 1976, The ${ }^{14} \mathrm{C}$ distribution in West Atlantic abyssal waters: Earth and Planetary Sci Letters, v 32, p 322-330.

1978, Atmospheric carbon dioxide and carbon reservoir changes: Science, v 199 , no. 4326 , p 253-258.

Vogel, J C, 1972, Radiocarbon in the surface waters of the Atlantic Ocean, in Rafter, $T A$ and Grant-Taylor, ' $T$, eds, Internatl radiocarbon dating conf, 8 th, Proc: Wellington, New Zealand, Royal Soc New Zealand, C44-C55. 